\title{
Social media and sports: driving fan engagement with football clubs on Facebook
}

\section{Leonor Vale \& Teresa Fernandes}

To cite this article: Leonor Vale \& Teresa Fernandes (2018) Social media and sports: driving fan engagement with football clubs on Facebook, Journal of Strategic Marketing, 26:1, 37-55

To link to this article: http://dx.doi.org/10.1080/0965254X.2017.1359655

曲 Published online: 03 Nov 2017.

Submit your article to this journal ¿

Q View related articles ¿ك

View Crossmark data ־ 


\title{
Social media and sports: driving fan engagement with football clubs on Facebook
}

\author{
Leonor Vale (iD) and Teresa Fernandes \\ Faculty of Economics, University of Porto, Porto, Portugal
}

\begin{abstract}
Sport fans develop unique and engaging relationships with their favourite sport teams, both offline and online. However, research on sport fan engagement is still limited in relation to social media. The purpose of this research is to understand why and how sport fans engage with clubs on social media. Following the Uses and Gratifications approach and the Consumers' Online Brand-Related Activities framework, seven motivations (Information, Entertainment, Personal Identity, Integration and Social Interaction, Empowerment, Remuneration and Brand Love) and three dimensions of online engagement behaviours (Consumption, Contribution and Creation) were considered. A web-based survey was conducted among football club fans of a major UEFA league on Facebook, resulting in 562 responses. The need for Information, Empowerment and Brand Love mainly drive Consumption, Contribution and Creation, respectively, while the need for Integration and Social Interaction emerged as the second most important motivation overall. This study contributes to the emerging research on social media use in the sport marketing literature, thus revealing additional opportunities for managers to engage their fan base online.
\end{abstract}

\section{ARTICLE HISTORY}

Received 28 October 2016 Accepted 20 July 2017

\section{KEYWORDS}

Sport; football clubs; fans; engagement; motivations; social media

\section{Introduction}

The sports marketing literature suggests that consumers of sports have unique relationships with their favourite teams (Abosag, Roper, \& Hind, 2012). These high levels of fandom, team identification and emotional attachment towards sport clubs have often been associated with the term 'engage' in the sport marketing literature (Yoshida, Gordon, Nakazawa, \& Biscaia, 2014). Highly engaged fans are likely to develop non-transactional behaviours such as positive word-of-mouth; displays of sport fandom; consumer-to-consumer interactions in fan communities; and reading information about the team (Ahearne, Bhattacharya, \& Gruen, 2005; deRuyter \& Wetzels, 2000). Actively contributing to value co-creation (Popp, Germelmann, \& Jung, 2016), sport fans are a classic example of loyal supporters of their clubs in good and bad times, maintaining an enduring and unique relationship with a team they regard as their own (Abosag et al., 2012). These and other unique behavioural patterns in spectator sport can be considered important manifestations of customer engagement 
behaviours (CEB), defined as 'customers' behavioural manifestations toward a brand or firm, beyond purchase, resulting from motivational drivers' (vanDoorn et al., 2010, p. 254).

Given existing fan bases and their level of sport fandom, sport organizations are ideally positioned to benefit from social media as an engagement platform (McCarthy, Rowley, Ashworth, \& Pioch, 2014; Williams \& Chinn, 2010). Social media has changed the way supporters engage with sports teams, athletes and other fans (loakimidis, 2010). Most sport fans are very engaged and, for many, sport plays an important role in their everyday lives (Popp, Wilson, Horbel, \& Woratschek, 2016). Due to the popularity of social media, sport clubs increasingly invest significant time and resources to drive online engagement, leveraging the highly involved nature of their fans (Filo, Lock, \& Karg, 2015; Hur, Ko, \& Valacich, 2007). However, there seems to be a lack of real effort to know their fan base, and many clubs still struggle with the dilemma of wanting to have control over their brand, while at the same time building an engaging presence with their empowered fan community (McCarthy et al., 2014). In fact, notwithstanding the large investments made, most clubs slowly moved into engaging with supporters via meaningful social media activity. As such, in the sport management literature, research devoted to fan engagement has deserved limited attention (Mahan, 2011; Stavros, Meng, Westberg, \& Farrelly, 2014), particularly on social media (Wallace, Wilson, \& Miloch, 2011) and from the fan perspective (Clavio \& Kian, 2010; Stavros et al., 2014). In fact, although research investigating issues on sport consumers' engagement spans nearly 30 years, most studies have been developed offline and focused on transactional behaviours (Yoshida et al., 2014), while the few developed online fail to consider a full set of behaviours and motivations associated with social media engagement, lacking theoretical depth (Filo et al., 2015). However, in order to use social media effectively, clubs need proper guidance on how to manage their presence online, namely by gaining more insights about their fans, motivations and behaviours.

Given the limitations of previous research, we draw on insights from social media, sports and engagement to identify the drivers of fans CEB while interacting with sport clubs on Facebook. The study argues that consumer's motivations are associated with a range of Facebook functionalities (e.g. posts, comments, shares) which can lead to a more complete perception of CEB on social media. In order to establish consumer's motivations, this study is theoretically grounded in the Uses and Gratifications approach (U\&G), one of the most widely used frameworks within the growing literature base related to sport and social media (Filo et al., 2015). Moreover, to determine the predictive value of motivations, we will measure a full set of online CEB (e.g. liking, sharing) through different degrees of consumer activities (Tsai \& Men, 2013). Based on the Consumer's Online Brand-Related Activities (COBRA) framework (Muntinga, Moorman, \& Smit, 2011), three dimensions were considered: Consumption, Contribution and Creation (Schivinski, Christodoulides, \& Dabrowski, 2016). As such, our aim is to understand not only why but also how fans engage with sport clubs on social media.

The paper is structured as follows. First, a literature review on social media engagement behaviours and its drivers, as well as the investigation undertaken to test the conceptual framework, is described. A web-based survey was then conducted among Facebook fans of professional clubs of one of the top five European football leagues, resulting in 562 responses. The research findings section presents and discusses the issues and benefits of CEB on social media sport clubs. Finally, we conclude by presenting the conclusions, contributions and suggestions for future research. 


\section{Social media engagement behaviours: the COBRA framework}

The growth of social media has established a new dynamic in marketing. Social media platforms allow consumers to engage in extensive brand-related activities (Hollebeek \& Brodie, 2016), enabling dynamic, ubiquitous and often real-time communication between brands and consumers, as well as large-scale consumer-to-consumer interactions (Dholakia, Bagozzi, \& Pearo, 2004; Gensler, Volkner, Liu-Thompkins, \& Wiertz, 2013). Engagement is particularly relevant within communities on social networking sites (SNS), such as Facebook brand pages, through which organizations are allowing consumers to engage with the brand, while at the same time being able to share their activities within their social group (Tsai \& Men, 2013). Namely, sport has been mentioned as a perfect example of a strong common interest for developing successful online communities (Popp et al., 2016), given existing fan bases and their level of sport fandom (Williams \& Chinn, 2010). In the sports marketing field, fans are considered a widely diverse group, found in every socio-economic class and education level, and the interpersonal dimensions of the relationship between fans and the object of fandom can be assessed by the validity of different psychoanalytic approaches to pleasure, desires and self-identity in fandom (Sandvoss, 2005). Fans may exhibit distinct fandom levels (Hunt, Bristol, \& Bashaw, 1999), ranging from attending games to assuming the successes and losses of their club as their own. But the degree of passion and emotional significance distinguishes a sport fan from a mere spectator (Dionisio, Leal, \& Moutinho, 2008). Social media offers fans new landscapes of fandom and an additional mean to engage with their favourite teams and clubs, while at the same time allows sport organizations to strengthen fan relationships (McCarthy et al., 2014; Stavros et al., 2014). Within social media, customers become co-owners and co-creators of brands (including club brands) and play a strong, empowering role in building brand reputation and image (Williams \& Chinn, 2010). However, most clubs still struggle with the dilemma of wanting to have control over their brand, while at the same time building an engaging presence with their fan community. Nevertheless, even though views expressed by some 'activist' fans (Hollebeek, 2011) on social media may not always be what sport managers want to hear, clubs who fail to release some control and to engage with their supporters may be potentially limiting the opportunity for enhancing relationship bonds with their fan base (McCarthy et al., 2014).

Given the new possibilities provided for customers' empowerment, social media has become one of the main channels through which consumers engage and interact with brands (Dolan, Conduit, Fahy, \& Goodman, 2016). While certain conceptualizations of engagement focus on its multidimensional nature (e.g. Brodie, Hollebeek, Juric, \& llic, 2013; Dessart, Veloutsou, \& Morgan-Thomas, 2016; Hollebeek, Glynn, \& Brodie, 2014), others have defined it with reference to specific customer activities or patterns (e.g. Dolan et al., 2016; vanDoorn et al., 2010; Schivinski et al., 2016). As such, vanDoorn et al. (2010) define CEB as 'customers' behavioural manifestations toward a brand or firm, beyond purchase, resulting from motivational drivers' (p. 254). Moreover, engagement reflects motivation, resulting from an individual's (the 'engagement subject') interactive experiences with a focal object (the 'engagement object'), which may include product offerings, events, organizations, media or interactions with a focal brand (Hollebeek, 2011). The behavioural interpretation of engagement will be used as a basis for the analysis presented further in this paper.

Understanding CEB has become increasingly important since different types of brand-related activities on social media, ranging from merely reading and commenting posts to 
posting a message (Tsai \& Men, 2017), may entail different levels of engagement (Schivinski et al., 2016). Among typologies that classify social media behaviours into usage types, Muntinga et al. (2011) define these activities as COBRA ('Consumers' Online Brand-Related Activities'), a behavioural construct that 'provides a unifying framework to think about consumer activity pertaining to brand-related content on social media platforms' (p. 14). In their qualitative study, the authors analyse online activities of 20 consumers through instant messaging interviews. Considering that CEB can be characterized by differing levels, which are individual and/or context-specific (Bowden, 2009), the authors grouped COBRA into three hierarchical dimensions: Consumption, Contribution and Creation. These dimensions correspond to a path of gradual engagement with brands on social media, from low (passive) to high (active) activity (Malthouse, Haenlein, Skiera, Wege, \& Zhang, 2013).

Consumption covers activities associated with a minimum level of engagement such as viewing brand-related posts, clicking on content or reading reviews others post, without actively participating (Dolan et al., 2016). This is the most frequent type of activity (Muntinga et al., 2011). Contribution, the mid level of engagement, covers both interactions with others or the brand, such as liking content, sharing or commenting, turning consumers into brand endorsers (Dolan et al., 2016). This dimension refers only to the participation of the consumer in media previously created by the brand or other source (Schivinski et al., 2016). Finally, Creation, the highest level of engagement, relates to actively producing, publishing and co-developing brand-related content, including posting reviews, uploading photos and using hashtags (Dolan et al., 2016). The content consumers generate may be a stimulus for further consumption or contribution by peers (Muntinga et al., 2011). Thus, the COBRA framework covers a wide array of social media engagement behaviours, ranging from reading tweets to posting a review (Gensler et al., 2013). Later on, this framework was validated through the 'Consumer's Engagement with Brand-Related Social Media Content' scale by Schivinski et al. (2016), using qualitative and quantitative methods. Their results further showed the existence of a hierarchical relationship among the three dimensions of brand-related activities.

In their conceptual work, Dolan et al. (2016) further capture not only the intensity, but also the valence of brand-related activities, by considering positively and negatively valenced engagement (Hollebeek \& Chen, 2014). Dolan et al. (2016) name these activities'Social Media Engagement Behaviours', defined as'customer's behavioural manifestations that have a social media focus, beyond purchase, resulting from motivational drivers' (p. 265).

Importantly, this definition reflects that CEB are a result of motivational influences. To date, however, fan motives for engaging in SNS brand-related activities has been scarcely investigated (Muntinga et al., 2011). Considering brand fan pages on SNS, past research has explored fans typology according to their reasons for liking brands (Wallace, Buil, deChernatony, \& Hogan, 2014) and drivers of brand posts popularity (measured by the number of likes and comments) among fans (deVries, Gensler, \& Leeflang, 2012). However, existing research on brand virtual communities (e.g. Dholakia et al., 2004; Gummerus, Liljander, Weman, \& Pihlström, 2012) overlooks the specific motivations associated to the multitude and degree of activities fans can develop in SNS (Baldus, Voorhees, \& Calantone, 2015), considering mainly general brand-related activities.

In the sports marketing field, the literature presents similar gaps. Research has mainly explored how social media can be used in the communication efforts of sport organizations and professional athletes (Meng, Stavros, \& Westberg, 2015; Wallace et al., 2011; Williams \& 
Chinn, 2010), with few studies dedicated to the fan perspective (Clavio \& Kian, 2010). Moreover, research on fan motives for engaging through social media has been limited and scattered through multiple platforms and perspectives (Filo et al., 2015), while relying mainly on a limited set of CEB, such as comments posted (Stavros et al., 2014) or general use, follow and consumption (Clavio \&Walsh, 2013; Gibbs, O'Reilly, \& Brunette, 2014). Hence, a greater understanding of the motivations of sport fans for social media engagement is required (Stavros et al., 2014).

\section{Drivers of social media engagement behaviours: the U\&G approach}

In the context of media use, motivations are understood as the incentives that drive people's selection of media (Rubin, 1983). Given the unique interactive nature of SNS, which link consumers to brands, while simultaneously broadcasting these interactions to the fan's and the brand's network, these online platforms are expected to satisfy a wider range of needs. One common approach in the literature when it comes to motivations related with types of media use is the U\&G theory (Katz, Haas, \& Gurevitch, 1973).

U\&G theory focuses on the gratifications that voluntarily attract audiences to certain media types and content in order to meet their needs and desires (Dunne, Lawlor, \& Rowley, 2010). U\&G researchers usually speak of motivations as gratifications sought, and describe why people consume certain media and the level of satisfaction they receive thereof (Ko, Cho, \& Roberts, 2005). Recent studies (Smock, Ellison, Lampe, \& Wohn, 2011; Sundar \& Limperos, 2013) claim that needs can be triggered by features experienced while using a specific media. Hence, rather than being used to examine what media does to people, U\&G has been employed to examine how and why people use media, or what they do with it (Dunne et al., 2010).

In recent years, a number of researchers have applied the U\&G approach in the context of social media. Since U\&G assumes that people are active, rather than passive, in their media use, and social media entails the active participation of users and a high level of interactivity (Ko et al., 2005), it can be extended to investigate CEB within social media. U\&G can thus be considered a 'cutting-edge approach' (Muntinga et al., 2011, p. 17) to understand individual motivations for media use.

U\&G researchers have identified several motivations for media use. The most widely recog-nised categorisation of U\&G motivations is the one mentioned by McQuail (1983), who labelled them into the following categories:

- Information: It relates to the need of accessing information directly from brands. It refers to the need of staying updated about the brand or learning from other consumers' knowledge (Gummerus et al., 2012; Muntinga, 2013; Zaglia, 2013), and may drive Consumption and Contribution (Guosong, 2009; Park, Kee, \& Valenzuela, 2009).

- Entertainment: It relates to the need of relaxation and evasion from daily routine through brand-related activities (Baldus et al., 2015; Muntinga, 2013), and can be a driver of engagement. Muntinga et al. (2011) found that entertainment is a key motivation for Consumption, Contribution and Creation.

- Personal Identity: It relates to the need of shaping one's identity through self-expression and self-presentation by providing an image of one's personality and by receiving peer 
recognition (Schau \& Gilly, 2003). Previous studies (Guosong, 2009; Muntinga, 2013; Tsai \& Men, 2017) relate it with Contribution and Creation.

- Integration and Social Interaction: It relates to the need of bonding with people with a common passion, gaining a sense of belonging to a community and meeting likeminded others (Baldus et al., 2015). It was found to be related with Consumption, Contribution and Creation (Muntinga et al., 2011; Park et al., 2009).

In the extant literature on social media, these motivations often occur along with the following others:

- Empowerment: It relates to the need of influencing other consumers or brands, playing the role of opinion maker (Muntinga, 2013; Sundar \& Limperos, 2013). Social media constitutes an important channel for consumers to voice their opinions and to demand brand improvements (McCarthy et al., 2014). Empowerment was found as a driver for Creation within brand SNS pages (Tsai \& Men, 2017).

- Remuneration: Consumers may engage with social media to gain some kind of reward (Dolan et al., 2016), such as a monetary compensation, giveaways or prizes (Baldus et al., 2015; Muntinga, 2013). Remuneration was found as a motivation for Consumption (Muntinga et al., 2011), and it may be associated to activities intended to promote a brand and its offerings.

- Brand Love: It relates to a strong positive feeling towards a brand (Albert, Merunka, \& Valette-Florence, 2009). Brand love is 'the degree of passionate emotional attachment a satisfied customer has for a particular trade name' (Carroll \& Ahuvia, 2006, p. 81). The link with online active engagement has been identified in the literature (Bergkvist \& Bech-Larsen, 2010).

U\&G theory has also been used in sport and social media research (Filo et al., 2015). In the context of NCAA Athletics, Clavio and Walsh (2013) identified the needs for interaction and information as motivations for the use of Facebook and Twitter. The same motivations were found by Gibbs et al. (2014) as the main drivers of Twitter followers of the Canadian Football League, together with promotions. Beyond U\&G, Whitemkaper, Lim, and Waldburger (2012) adapted the motivation scale of Seo and Green (2008) from a website context to social media in order to analyse drivers for following athletes on Twitter. Information, entertainment, pass-time and friendship were identified as important motivations. Finally, Stavros et al. (2014) developed a qualitative study to uncover motivations for fan engagement with NBA teams on Facebook. Through a content analysis of fan comments, the authors identified passion, hope, esteem and camaraderie as engagement drivers. However, even though this (relatively small) body of research provides valuable insights, these studies only investigated the motivations for general brand-related activities and fail to consider a full set of behaviours associated with social media engagement.

\section{Research framework and methodology}

The purpose of our research is to identify the motivations that drive engagement with sport clubs on social media. The chosen platform for this study, Facebook, is the most popular SNS, currently surpassing 1 billion worldwide active users (Statista, 2016). Facebook includes items associated with e.g. 'liking', reviewing and sharing content, 'facilitating text, pictorial, 
video, gaming and other forms of communication' (Hollebeek et al., 2014, p. 155). These types of interactions allow sports entities and other organizations to establish relationships and a strong brand presence (Wallace et al., 2011). Moreover, in Facebook, users choose to become fans of certain pages or members of subgroups around a certain topic, such as a brand. They do this by clicking on the button 'I like', and brands then use it to broadcast information in an official, public manner to people who choose to connect with them (Zaglia, 2013). Though these pages are built around a brand, Facebook (unlike e.g. Twitter) is mainly oriented toward facilitating social connectedness (Smith, Fischer, \& Yongjian, 2012), and hence the success of these communities largely depends on the relationships established among its members or fans. Understanding Facebook fans thus provides valuable insights into brand engagement (Wallace et al., 2014).

Our aim is to understand both why and how customers engage with football clubs on social media, theoretically grounded on the U\&G approach and the COBRA framework, adapted to a sports context. As such, this work explores consumer's motivations, associated with a range of Facebook functionalities (e.g. posts, comments, shares) for a more complete perception of social media engagement behaviours. As such, following Tsai and Men (2017) conceptualization, based on Muntinga et al. (2011) typology, this study considers engagement on social media as:

a behavioural construct with hierarchical activity levels, from passive message consumption (e.g., viewing videos and pictures, reading product reviews) to active content contributing which includes two-way conversation, participation and online recommendation (e.g., responding to comments and other SNS posts, posting one's own product reviews, uploading user-created videos and pictures). (Tsai \& Men, 2017, p. 6)

Therefore, our study will focus on the intensity of engagement behaviours, namely Consumption, Contribution and Creation activities (Muntinga et al., 2011), considering that fans exhibit distinct fandom levels (Hunt et al., 1999), and hence will display different, gradual levels of CEB towards the club on social media. Though we are aware that sport fandom is a multisensory phenomenon that raises several responses, sometimes unfavourable and negative such as anger or frustration (Grove, Pickett, Jones, \& Dorsch, 2012; Hunt et al., 1999; Wakefield \&Wann, 2006), our study will not differentiate the valence of social media engagement behaviours (Dolan et al., 2016; Hollebeek \& Chen, 2014; Popp et al., 2016).

Given the exploratory nature of our research, attention will be given to the following hypotheses:

Hypothesis 1 (H1): The need for (a) Information, (b) Entertainment, (c) Personal Identity, (d) Integration and Social Interaction, (e) Empowerment, (f) Remuneration and (g) Brand Love influences engagement with a football club on Facebook, namely Consuming activities.

Hypothesis 2 (H2): The need for (a) Information, (b) Entertainment, (c) Personal Identity, (d) Integration and Social Interaction, (e) Empowerment, (f) Remuneration and (g) Brand Love influences engagement with a football club on Facebook, namely Contributing activities.

Hypothesis 3 (H3): The need for (a) Information, (b) Entertainment, (c) Personal Identity, (d) Integration and Social Interaction, (e) Empowerment, (f) Remuneration and (g) Brand Love influences engagement with a football club on Facebook, namely Creating activities. According to literature review, we present the following research framework (Figure 1): 


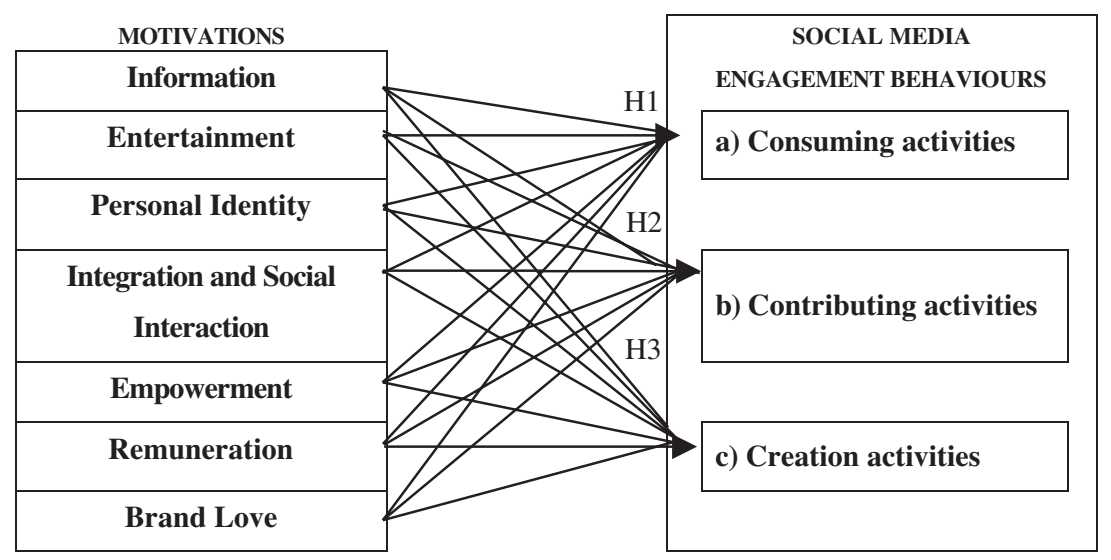

Figure 1. Research framework.

Professional clubs of one of the top five European football leagues according to the latest 2011-2016 UEFA rankings were chosen for this study, based on the popularity of these clubs on society in general and on Facebook. For the empirical study, respondents were invited by mail and through social media posts to participate in a web-based self-administered survey about the official Facebook pages of professional league teams. Respondents were asked to choose a club whose Facebook page they followed, resulting in a convenience sample of 562 responses, representing 19 sport clubs out of a total of 36 possible clubs. The questionnaire comprised 47 questions regarding demographic data, (seven) motivations and (three) dimensions of social media engagement behaviour. Measures were based on multi-item scales established in previous research and assessed in a seven-point Likert scale (Appendix A). Main results are shown in the following section.

\section{Research findings and discussion}

The majority of respondents, chosen from the club's fan base on Facebook, followed one of the league's three most popular clubs (77.9\%). The respondents are both men (53\%) and women (47\%), predominantly between 18 and 25 years old (52.1\%), with a high education level (62.7\%) and mostly college students (47.3\%).

Confirmatory factor analysis using AMOS 22.0 was applied for testing the measurement model. Composite measures of identified factors of both engagement drivers and online engagement behaviours were unidimensional and demonstrated good scale reliability (Nunnally, 1978). One of the items measuring personal identity reduced scale reliability and was removed. Overall fit indices suggested a good fit of data $X^{2}(628)=1992.191, p<.00\left(X^{2} /\right.$ $\mathrm{df}=3.172, \mathrm{CFI}=.926, \mathrm{TLI}=.901, \mathrm{RMSEA}=.062, \mathrm{SRMR}=.0645)$. Moreover, internal reliability tests showed strong Cronbach's alpha (ranging from .725 to .847). Composite Reliability (CR) and Average Variances Extracted (AVE), estimates were above recommended minimums of .70 and .50, respectively (Hair, Black, Babin, \& Anderson, 2014). Thus, the factors demonstrated good internal consistency and high levels of convergence both for engagement drivers (Table 1) and online behaviours (Table 2).

Convergent and discriminant validity were also demonstrated. All factor loadings for indicators measuring the same construct were statistically significant $(p<.01)$, supporting 
Table 1. Measurement scales, reliability and dimensionality statistics: drivers of consumer engagement on social media.

\begin{tabular}{|c|c|c|c|}
\hline Measures & Loadings & Means & CR (AVE) \\
\hline Information $(\alpha=.725)$ & & 4.76 & $.834(.558)$ \\
\hline The sport-related information is useful & .789 & 5.45 & \\
\hline I want to know what other people think about the sport club & .683 & 3.85 & \\
\hline $\begin{array}{l}\text { I can get information about team performance, player profiles, events and games } \\
\text { scheduled }\end{array}$ & .804 & 5.75 & \\
\hline It helps me in forming an opinion about the sport club & .704 & 3.99 & \\
\hline Entertainment $(\alpha=.807)$ & & 3.77 & $875(.636)$ \\
\hline I like participating in this community because it is entertaining & .771 & 4.76 & \\
\hline The community provides an outlet for me to escape my daily routine & .817 & 2.82 & \\
\hline It arouses my emotions and feelings & .766 & 4.27 & \\
\hline It relaxes me & .835 & 3.24 & \\
\hline Personal identity $(\alpha=.823)$ & & 2.68 & $.898(.745)$ \\
\hline I want to express what kind of person I am & .827 & 3.28 & \\
\hline It gives me self-confidence & .901 & 2.31 & \\
\hline I want to impress others with what I know about the sport club & .860 & 2.44 & \\
\hline Integration and social interaction $(\alpha=.768)$ & & 3.80 & $.853(.592)$ \\
\hline $\begin{array}{l}\text { I look forward to talking, discussing, and sharing information with others that } \\
\text { also like the sport club }\end{array}$ & .832 & 3.80 & \\
\hline Being part of this community makes me feel more connected to the sport club & .793 & 3.88 & \\
\hline It makes me feel less lonely & .694 & 2.20 & \\
\hline I feel closer to the sport club & .753 & 5.31 & \\
\hline Empowerment $(\alpha=.841)$ & & 2.73 & $.930(.767)$ \\
\hline I want to influence the club to do, or to leave, something & .865 & 2.68 & \\
\hline I want to influence other people & .884 & 2.52 & \\
\hline $\begin{array}{l}\text { I feel good about myself when other community members share my ideas and } \\
\text { comments }\end{array}$ & .866 & 3.02 & \\
\hline $\begin{array}{l}\text { Receiving more affirmation about my comments makes me want to participate in } \\
\text { the community }\end{array}$ & .889 & 2.70 & \\
\hline Remuneration $(\alpha=.759)$ & & 3.40 & $.748(.582)$ \\
\hline $\begin{array}{l}\text { When I want to buy a ticket, I use the club's community to search for bargain } \\
\text { prices }\end{array}$ & .821 & 2.87 & \\
\hline $\begin{array}{l}\text { I'm motivated to participate in this community because I can earn money, prizes } \\
\text { or discounts }\end{array}$ & .770 & 3.13 & \\
\hline I am able to obtain information I want without any delay & .700 & 4.01 & \\
\hline I want to get a better service & .757 & 3.59 & \\
\hline Brand love $(\alpha=.847)$ & & 5.62 & $.908(.712)$ \\
\hline $\begin{array}{l}\text { I'm motivated to participate in the community because I'm passionate about the } \\
\text { sport club }\end{array}$ & .903 & 5.90 & \\
\hline I associate the sport club with some important events of my life & .777 & 4.55 & \\
\hline I participate in the community because I care about the sport club & .863 & 5.94 & \\
\hline I identify myself with the sport club & .827 & 6.09 & \\
\hline
\end{tabular}

Note: $\alpha$ : Cronbach's alpha; CR: Composite Reliability; AVE: Average Variance Extracted. The values on the third column are all means.

convergent validity. Moreover, estimated pair-wise correlations between factors (i) did not exceed .85 and were significantly less than one (Bagozzi \& Yi, 1988); and (ii) the square root of AVE for each construct was higher than the correlations between them (Fornell \& Larcker, 1981), thus supporting discriminant validity (Anderson \& Gerbing, 1988), as shown on Table 3.

Hypotheses 1 through 3 aimed to determine to what extent Consumption, Contribution and Creation were explained by the motivations considered. Standardized regression weights and square multiple correlations are presented on Table 4. The main motivation associated to Creation was Brand Love, while Empowerment was the main driver of Contribution. Finally, Consuming was mainly related with Information needs.

The main role of Brand Love in explaining the strongest form of engagement, Creation $(\beta=.233)$, reveals the importance of high levels of consumer bonds with sport clubs (Albert et al., 2009). Brand Love also had the highest mean score out of all the motivations 
Table 2. Measurement scales, reliability and dimensionality statistics: consumer engagement behaviours on social media.

\begin{tabular}{|c|c|c|c|}
\hline Measures & Loadings & Means & CR (AVE) \\
\hline Consuming $(\alpha=.823)$ & & 5.11 & $.917(.736)$ \\
\hline I read the content posted by the sport club on Facebook & .865 & 5.40 & \\
\hline I view pictures or photos posted by the sport club on Facebook & .891 & 5.56 & \\
\hline I watch videos posted by the sport club on Facebook & .888 & 5.21 & \\
\hline $\begin{array}{l}\text { I read posts, forum threads, and comments of others about the sport club on } \\
\text { Facebook }\end{array}$ & .782 & 4.27 & \\
\hline Contributing $(\alpha=.776)$ & & 3.45 & $.908(.711)$ \\
\hline I'like' content posted by the sport club on Facebook & .765 & 4.89 & \\
\hline $\begin{array}{l}\text { I share content posted by the sport club on my own Facebook page or with my } \\
\text { friends }\end{array}$ & .870 & 3.52 & \\
\hline $\begin{array}{l}\text { I comment on posts, videos, images or forums posted by the sport club on } \\
\text { Facebook }\end{array}$ & .876 & 2.71 & \\
\hline $\begin{array}{l}\text { I comment posts, forum threads, and comments of others about the sport club } \\
\text { on Facebook }\end{array}$ & .857 & 2.69 & \\
\hline Creating $(\alpha=.822)$ & & 2.93 & $.909(.714)$ \\
\hline I initiate posts related to the sport club on my Facebook page & .877 & 3.64 & \\
\hline I post pictures, videos or personal images related to the sport club on Facebook & .881 & 2.93 & \\
\hline I add labels or hashtags on my posts related to the sport club on Facebook & .806 & 2.78 & \\
\hline $\begin{array}{l}\text { I write reviews, forum threads and personal opinions related to the sport club on } \\
\text { Facebook }\end{array}$ & .813 & 2.37 & \\
\hline
\end{tabular}

considered, due to the passion, care and sense of identification felt by respondents towards the club. Given its hedonic and self-expressive nature, sports are typically characterized by a high degree of emotional involvement, difficult to attain by many commercial brands, and are often consumed in an irrational manner (Abosag et al., 2012). Brand Love as been associated with high levels of fanship (Wallace et al., 2014), which includes an emotional connection to a team, and is 'active, participatory, and empowering, with the passion and pleasure it creates' (Whitemkaper et al., 2012, p. 173). Past research has stressed the importance of emotional intensity in consumer behaviour (Carroll \& Ahuvia, 2006), namely extrarole behaviours (Yoshida et al., 2014), which in a sport context are pro-social, effort-intensive behaviours, beyond transactions, directed toward a sport team and other fans (deRuyter \& Wetzels, 2000). The love for the club and team identification is where these passionate behaviours originate (Dionisio et al., 2008), which may include advocacy (e.g. writing reviews) and displays of sport fandom (e.g. creating posts about the club). By providing common symbols and a collective identity, sports arouse Brand Love by offering more to the consumer in terms of symbolic benefits (Carroll \& Ahuvia, 2006), leading to active, higher forms of engagement (Bergkvist \& Bech-Larsen, 2010).

The analysis further indicated Empowerment as the main motivation regarding Contribution ( $\beta=$.397). The idea that one can influence other people's perceptions, or get a brand to change their course of action, also appears as an important motivator for Creation $(\beta=.156)$. Empowered by social media, impassioned, united and expert customers are now able to impact brands and other customers: some power shifted from the company to its customers, placing them on equal footing (Cova \& Pace, 2006). In a sport context, social media enables these 'prosumers' to develop their own voices in the form of user-generated content or opinions and, thus, adds value to their relationship with clubs through a sense of empowerment (McCarthy et al., 2014; Williams \& Chinn, 2010). Therefore, empowerment 


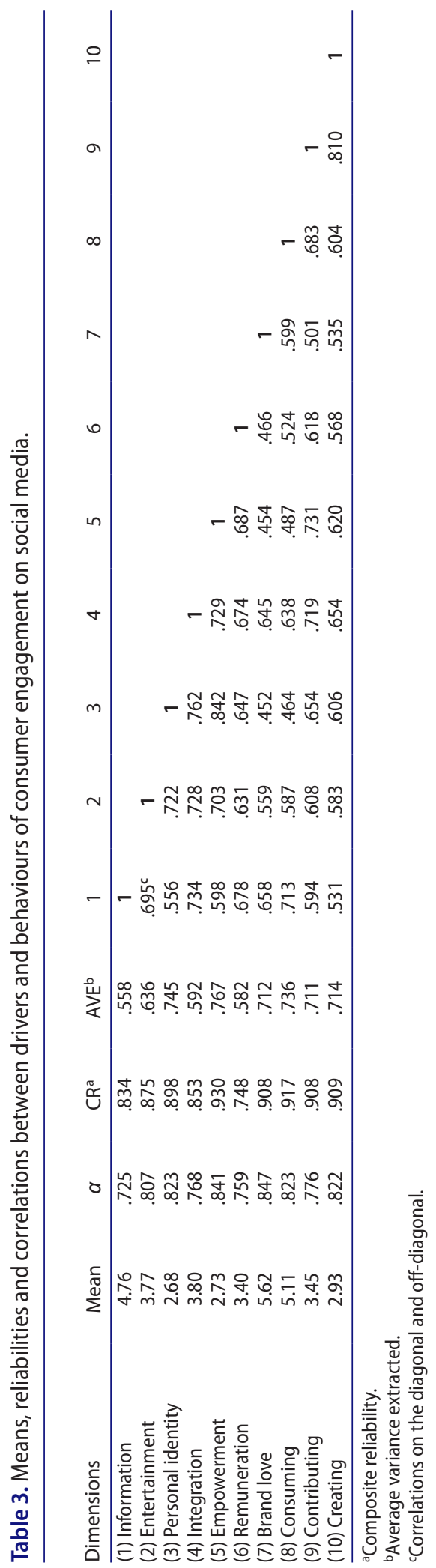


Table 4. Hypotheses testing results: standardized regression weights and square multiple correlations.

\begin{tabular}{lccc}
\hline & \multicolumn{2}{c}{ Standardized Regression Weights } \\
\cline { 2 - 4 } Drivers of consumer engagement on social media & Consumption & Contribution & Creation \\
\hline Information & $.433^{*}$ & $\mathrm{~ns}$ & $\mathrm{~ns}$ \\
Entertainment & $\mathrm{ns}$ & $\mathrm{ns}$ & $\mathrm{ns}$ \\
Personal Identity & $\mathrm{ns}$ & $\mathrm{ns}$ & $.121^{* *}$ \\
Integration and social interaction & $.197^{*}$ & $.250^{*}$ & $.190^{*}$ \\
Empowerment & $\mathrm{ns}$ & $.397^{*}$ & $.156^{* *}$ \\
Remuneration & $\mathrm{ns}$ & $.112^{*}$ & $.156^{*}$ \\
Brand love & $.168^{*}$ & $.079^{* *}$ & $.233^{*}$ \\
$R^{2}$ & .550 & .598 & .497 \\
\hline
\end{tabular}

Note: ns: Non-significant.

"Significant at $p<.01 ;{ }^{* *}$ Significant at $p<.05$.

creates a deeper connection and higher engagement with the sport brand (Acar \& Puntoni, 2016). As expected, the impact of Empowerment in Consumption was not significant, since consuming does not allow users to control the production and distribution of content, nor to exert influencing power upon others (Muntinga et al., 2011).

Unsurprisingly, Information was the main motivation regarding the lowest form of engagement, Consumption $(\beta=.433)$. As such, sport fans engage with clubs on social media as they seek for up-to-date information about events, products, teams and players (Clavio \&Walsh, 2013; Hur et al., 2007). Other studies (Cvijikj \& Michaelles, 2013; deVries et al., 2012) have reported that informational content mainly causes lower, passive levels of engagement and does not elicit online interactions, since informational needs are satisfied without actively having to contribute or create.

The need for Integration and Social Interaction was considered the second most important motivation across all three engagement dimensions considered, pointing out the value of sharing opinions regarding team performance and developing fans' social interactions (Hur et al. 2007). Sport clubs provide 'an increasingly rare sense of community in today's rapidly disconnecting society' and are 'a unique group experience characterized by a sense of belonging' felt by supporters (Abosag et al., 2012, p;.1236). These supporters develop tribal behaviours (Cova \& Pace, 2006), through a sense of affiliation, social recognition, symbolism and socialization (Dionisio et al., 2008; Popp et al., 2016). According to Smock et al. (2011), these customers with high social interaction needs are more likely to develop higher, active levels of CEB, such as providing comments and participating in online discussions. The communal atmosphere and active group interactions also encourage Creation (Tsai \& Men, 2013).

Results further revealed that Remuneration was only significant for Contribution $(\beta=.112)$ and Creation ( $\beta=$.156). Fans also engage with clubs as they seek benefits, such as to save or make money, or obtain free event tickets (Hur et al., 2007). The impact of Remuneration needs hasn't reached a consensus in the literature, with Muntinga et al. (2011) relating them only to low levels of engagement, while others authors (Cvijikj \& Michaelles, 2013; Tsai \& Men, 2013) acknowledge the role of Remuneration on commenting, liking and following a brand page. Also Muntinga (2013) found some, yet little, predictive ability of Remuneration on Creation.

Finally, and unlike prior studies (Cvijikj \& Michaelles, 2013; Muntinga et al., 2011; Tsai \& Men, 2013), Entertainment was found overall as a non-significant motivation of engagement. Like Information, the Entertainment motivation is generally considered as a broad, unspecified motivational concept. This result is, however, consistent with the study of deVries et al. 
(2012). According to the authors, this might be explained by the fact that sport fans are actually interested in the club itself, and that entertaining content might be unrelated to it. This finding may also mean that sport fans are more likely to search for utilitarian than hedonic value (Baldus et al., 2015). Results showed as well that Personal Identity only impacts Creation ( $\beta=.121$ ), which corroborates previous studies (Guosong, 2009; Muntinga, 2013).

\section{Conclusion}

In the sport management literature, limited attention has been devoted to fan engagement and motivations, particularly within a social media context. Our study makes several contributions to the fields of sports, social media and engagement. We identify the drivers of fan engagement with football clubs on Facebook from the sport fan perspective. In order to do so, we have extended the U\&G perspective to the digital landscape, by considering a full set of motivations for social media use, adapted to a sports context. As such, the framework used in this study extends previous research by providing a single, combined model that merges both drivers and engagement behaviours on social media. In addition, this research defined social media engagement behaviour as a multidimensional construct, based on a three-level hierarchical typology of online brand-related uses, which provides better perception of the phenomenon, beyond more superficial outputs such as the number of followers or likes. As such, we were able to establish an empirical relationship, which was previously largely conceptual or only qualitatively examined, between drivers of different levels of CEB, and thus understand both why and how sport fans engage with football clubs on social media. Finally, and most importantly, the current study contributes significantly to the existing body of knowledge on sports marketing, where studies on social media and fan engagement are still scarce (Stavros et al., 2014), lack theoretical depth (Filo et al., 2015) and lag behind recent online developments (Wallace et al., 2011).

Research has mainly explored social media from the perspective of sport organizations and professional athletes, and the few studies focusing the fan perspective are limited and scattered through multiple platforms and perspectives, and do not account for the wide range of behaviours and motivations associated with social media engagement. Answering to calls for further research, our study extends research beyond offline, traditional, in-role sport management concepts such as attending sport events or purchasing team products, and moves towards a more integrated application of theory.

Our findings show that the need for Information, Empowerment and Brand Love are the main drivers of Consumption, Contribution and Creation, respectively. Furthermore, the need for Integration and Social Interaction also emerged as one of the main motivations for engaging with sport clubs on Facebook. Hence, our study reveals that the interactive and collaborative nature of social media can reinforce new, specific and more'social' motivations. Finally, Brand Love appeared as the main driver of the highest level of engagement, Creation, which reflects the unique relationships fans develop with their favourite sport teams.

In managerial terms, our findings provide guidance to sport marketers on how to retain loyal fans by evoking their desired gratifications. Given that clubs' resources are limited and that considerable investments are required to manage social and digital media, understanding fans engagement drivers has important implications for the design of football clubs'SNS pages, and can be used to promote targeted campaigns and one-to-one relationships. Given the importance of the Integration and Social Interaction and Empowerment motivations, 
sport clubs should ensure that their SNS pages foster fan-to-fan social interaction, giving them the leading role and a sense of power, in order to engage their fan base. As such, football clubs should enable fan expression, through discussion boards and walls used for dialogue between the sport organization and fans. Moreover, poll apps on Facebook, in which clubs ask their fans to vote, e.g. for the man of the match, is another way of engaging fans: e.g. Manchester United's 'Starting Striker' poll allows fans to give their opinion on the starting line-up of the team. Also, introducing power mechanisms such as influence rankings or social-bookmarking capabilities may help influencer fans to reach a broader audience and, hence, to enhance fan engagement with sport clubs. Sport organizations may also solicit inputs, e.g. giving fans the opportunity to personalize team products or to provide inputs on the future direction of the club. Considering the importance of Brand Love on the highest form of engagement, Creation, sport marketers could also develop competitions where fans could be invited to, e.g., produce content showing their love and how far would they go for the club, and showcase it on their page for other fans to see and vote. Clubs could promote other online displays of love to the club through profile picture filters for Facebook, allowing fans to showcase their support (e.g. regarding a particular match) by temporarily changing their profile photo. Since Information was considered the main driver of Consumption, football clubs should frequently disseminate updated information and exclusive contents on their Facebook pages, including a list of team events and photos, videos or audio files uploaded by the organization. Live video channels such as Facebook Live allow fans to engage in real time with the club, from player interviews to training and arrival to the stadium, as well as to watch 'behind-the-scenes' exclusives, such as players playing pranks on each other, and 'during-the-game' content. In order to keep feeding fans with news around the team, Manchester City FC has recently become the first football club to launch a social bot (i.e. an automation software able to hold a conversation and pass itself off as a human being) on Facebook Messenger, which will push out, e.g. photos, pre-match build up and match highlights. Finally, and since Remuneration was also considered a significant driver, it would be important for sport pages to offer incentives such as discounts or bargain prices associated with Contribution and Creation.

However, our study is not without limitations. Data were collected primarily using a convenience sample, which warrants caution in generalizing results. Moreover, the study was based on a single social media platform and was limited to a specific football league. Further research is needed to establish if these findings can be generalized to other SNS and other cultures, as well as to other leagues and team sports. Moreover, our research focused exclusively on the intensity of social media engagement behaviours, regardless of their valence. Studying also cognitive and affective components, as well as positive vs negative manifestations, could provide a more comprehensive understanding of engagement with football clubs on social media. Furthermore, future qualitative studies could gain more in-depth insights about this phenomenon in order to further articulate fans' viewpoints and experiences. Finally, future research could focus on the outcomes of social media engagement, such as fan loyalty, and examine the moderating effects of fan's individual variables on the relationship between motivations and online engagement.

\section{Disclosure statement}

No potential conflict of interest was reported by the authors. 


\section{ORCID}

Leonor Vale (iD) http://orcid.org/0000-0002-6638-6060

Teresa Fernandes (iD http://orcid.org/0000-0001-5753-2188

\section{References}

Abosag, I., Roper, S., \& Hind, D. (2012). Examining the relationship between brand emotion and brand extension among supporters of professional football clubs. European Journal of Marketing, 46, 1233-1251. doi:10.1108/03090561211247810

Acar, O., \& Puntoni, S. (2016). Customer empowerment in the digital age. Journal of Advertising Research, 56, 4-8. doi:10.2501/JAR-2016-007

Ahearne, M., Bhattacharya, C., \& Gruen, T. (2005). Antecedents and consequences of customer-company identification: Expanding the role of relationship marketing. The Journal of Applied Psychology, 90, 574-585. doi:10.1037/0021-9010.90.3.574

Albert, N., Merunka, D., \& Valette-Florence, P. (2009). The feeling of love toward a brand: Concept and measurement. Advances in Consumer Research, 36, 300-307.

Anderson, J., \& Gerbing, D. (1988). Structural equation modelling in practice: A review and recommended two-step approach. Psychological Bulletin, 103, 411-423. doi:10.1037/0033-2909.103.3.411

Bagozzi, R., \& Yi, Y. (1988). On the evaluation of structural equation models. Journal of the Academy of Marketing Science, 16, 74-94. doi:10.1007/BF02723327

Baldus, B., Voorhees, C., \& Calantone, R. (2015). Online brand community engagement: Scale development and validation. Journal of Business Research, 68, 978-985. doi:10.1016/j.jbusres.2014.09.035

Bergkvist, L., \& Bech-Larsen, T. (2010). Two studies of consequences and actionable antecedents of brand love. Journal of Brand Management, 17, 504-518. doi:10.1057/bm.2010.6

Bowden, J. (2009). The process of customer engagement: A conceptual framework. Journal of Marketing Theory and Practice, 17, 63-74. doi:10.2753/MTP1069-6679170105

Brodie, R., Hollebeek, L., Juric, B., \& llic, A. (2013). Consumer engagement in a virtual brand community: An exploratory analysis. Journal of Business Research, 66, 105-114. doi:10.1016/j.jbusres.2011.07.029

Carroll, B., \& Ahuvia, A. (2006). Some antecedents and outcomes of brand love. Marketing Letters, 17, 79-89. doi:10.1007/s11002-006-4219-2

Clavio, G., \& Kian, T. (2010). Uses and gratifications of a retired female athlete's Twitter followers. International Journal of Sport Communication, 3, 485-500. doi:10.1123/ijsc.3.4.485

Clavio, G., \& Walsh, P. (2013). Dimensions of social media utilization among college sport fans. Communication \& Sport, 2, 261-281. doi:10.1177/2167479513480355

Cova, B., \& Pace, S. (2006). Brand community of convenience products: New forms of customer empowerment - The case "my Nutella The Community". European Journal of Marketing, 40, 10871105. doi:10.1108/03090560610681023

Cvijikj, I., \& Michaelles, F. (2013). Online engagement factors on Facebook brand pages. Social Network Analysis and Mining, 3, 843-861. doi:10.1007/s13278-013-0098-8

Dessart, L., Veloutsou, C., \& Morgan-Thomas, A. (2016). Capturing consumer engagement: Duality, dimensionality and measurement. Journal of Marketing Management, 32, 399-426. doi:10.1080/ $0267257 X .2015 .1130738$

deRuyter, K., \& Wetzels, M. (2000). With a little help from my fans: Extending models of prosocial behaviour to explain supporters' intentions to buy soccer club shares. Journal of Economic Psychology, 21, 387-409. doi:10.1016/S0167-4870(00)00010-6

deVries, L., Gensler, S., \& Leeflang, P. (2012). Popularity of brand posts on brand fan pages: An investigation of the effects of social media marketing. Journal of Interactive Marketing, 26, 83-91. doi:10.1016/j.intmar.2012.01.003

Dionisio, P., Leal, C., \& Moutinho, L. (2008). Fandom affiliation and tribal behaviour: A sports marketing application. Qualitative Market Research, 11, 17-39. doi:10.1108/13522750810845531

Dholakia, U., Bagozzi, R., \& Pearo, L. (2004). A social influence model of consumer participation in network- and small-group-based virtual communities. International Journal of Research in Marketing, 21,241-263. doi:10.1016/j.ijresmar.2003.12.004 
Dolan, R., Conduit, J., Fahy, J., \& Goodman, S. (2016). Social media engagement behaviour: A uses and gratifications perspective. Journal of Strategic Marketing, 24, 261-277. doi:10.1080/096525 4X.2015.1095222

Dunne, A., Lawlor, M.-A., \& Rowley, J. (2010). Young people's use of online social networking sites A uses and gratifications perspective. Journal of Research in Interactive Marketing, 4, 46-58. doi:10.1108/17505931011033551

Filo, K., Lock, D., \& Karg, A. (2015). Sport and social media research: A review. Sport Management Review, 18, 166-181. doi:10.1016/j.smr.2014.11.001

Fornell, C., \& Larcker, D. (1981). Evaluating structural equation models with unobservable variables and measurement error. Journal of Market Research, 18, 39-50. doi:10.2307/3151312

Gensler, S., Volkner, F., Liu-Thompkins, Y., \& Wiertz, C. (2013). Managing brands in the social media environment. Journal of Interactive Marketing, 27, 242-256. doi:10.1016/j.intmar.2013.09.004

Gibbs, C., O'Reilly, N., \& Brunette, M. (2014). Professional team sport and Twitter: Gratifications sought and obtained by followers. International Journal of Sport Communication, 7, 188-213. doi:10.1123/ IJSC.2014-0005

Grove, S., Pickett, G., Jones, S., \& Dorsch, M. (2012). Spectator rage as the dark side of engaging sport fans: Implications for services marketers. Journal of Service Research, 15, 13-20. doi:10.1177/1094670511428166

Gummerus, J., Liljander, V., Weman, E., \& Pihlström, M. (2012). Customer engagement in a Facebook brand community. Management Research Review, 35, 857-877. doi:10.1108/01409171211256578

Guosong, S. (2009). Understanding the appeal of user generated media: A uses and gratification perspective. Internet Research, 19, 7-25. doi:10.1108/10662240910927795

Hair, J., Black, W., Babin, B., \& Anderson, R. (2014). Multivariate data analysis. Upper Saddle River, NJ: Prentice Hall, Pearson Education.

Hollebeek, L. (2011). Demystifying customer brand engagement: Exploring the loyalty nexus. Journal of Marketing Management, 27, 785-807. doi:10.1080/0267257X.2010.500132

Hollebeek, L., \& Brodie, R. (2016). Non-monetary social and network value: Understanding the effects of non-paying customers in new media. Journal of Strategic Marketing, 24, 169-174. doi:10.1080/0 965254X.2015.1097093

Hollebeek, L., \& Chen, T. (2014). Exploring positively-versus negatively-valenced brand engagement. Journal of Product \& Brand Management, 23, 62-74. doi:10.1108/JPBM-06-2013-0332

Hollebeek, L., Glynn, M., \& Brodie, R. (2014). Consumer brand engagement in social media: Conceptualization, scale development and validation. Journal of Interactive Marketing, 28, 149-165. doi:10.1016/j.intmar.2013.12.002

Hunt, K., Bristol, T., \& Bashaw, E. (1999). A conceptual approach to classifying sports fans. Journal of Services Marketing, 13, 439-452. doi:10.1108/08876049910298720

Hur, Y., Ko, Y., \& Valacich, J. (2007). Motivation and concerns for online sport consumption. Journal of Sport Management, 21, 521-539.

loakimidis, M. (2010). Online marketing of professional sport clubs: Engaging fans on a new playing field. International Journal of Sports Marketing \& Sponsorship, 12, 271-282. doi:10.1108/IJSMS-1104-2010-B002

Katz, E., Haas, H., \& Gurevitch, M. (1973). On the use of the mass media for important things. American Sociological Review, 38, 164-181. doi:10.2307/2094393

Ko, H., Cho, C.-H., \& Roberts, M. (2005). Internet uses and gratifications: A structural equation model of interactive advertising. Journal of Advertising, 34, 57-70. doi:10.1080/00913367.2005.10639191

Malthouse, E., Haenlein, M., Skiera, B., Wege, E., \& Zhang, M. (2013). Managing customer relationships in the social media era: Introducing the social CRM house. Journal of Interactive Marketing, 27, 270-280. doi:10.1016/j.intmar.2013.09.008

Mahan, J. (2011). Examining the predictors of consumer response to sport marketing via digital social media. International Journal of Sport Management and Marketing, 9, 254-267. doi:10.1504/ IJSMM.2011.041575

McCarthy, J., Rowley, J., Ashworth, C., \& Pioch, E. (2014). Managing brand presence through social media: The case of UK football clubs. Internet Research, 24, 181-204. doi:10.1108/IntR-08-2012-0154 
Meng, M., Stavros, C., \& Westberg, K. (2015). Engaging fans through social media: Implications for team identification. Sport, Business and Management: An International Journal, 5, 199-217. doi:10.1108/ SBM-06-2013-0013

McQuail, D. (1983). Mass communication theory. London: Sage.

Muntinga, D. (2013). Catching COBRAs. Amsterdam: University of Amsterdam.

Muntinga, D., Moorman, M., \& Smit, E. (2011). Introducing COBRAs Exploring motivations for brandrelated social media use. International Journal of Advertising, 30, 13-46. doi:10.2501/ija-30-1-013-046

Nunnally, J. (1978). Psychometric theory. New York, NY: McGraw-Hill.

Park, N., Kee, K., \& Valenzuela, S. (2009). Being immersed in social networking environment: Facebook groups, uses and gratifications, and social outcomes. CyberPsychology \& Behaviour, 12, 729-733. doi:10.1089/cpb.2009.0003

Popp, B., Germelmann, C., \& Jung, B. (2016). We love to hate them! Social media-based anti-brand communities in professional football. International Journal of Sports Marketing and Sponsorship, 17, 349-367. doi:10.1108/IJSMS-11-2016-018

Popp, B., Wilson, B., Horbel, C., \& Woratschek, H. (2016). Relationship building through Facebook brand pages: The multifaceted roles of identification, satisfaction, and perceived relationship investment. Journal of Strategic Marketing, 24, 278-294. doi:10.1080/0965254X.2015.1095226

Rubin, A. (1983). Television uses and gratifications: The interactions of viewing patterns and motivations. Journal of Broadcasting \& Electronic Media, 27, 37-51. doi:10.1080/08838158309386471

Sandvoss, C. (2005). Fans: The mirror of consumption. Cambridge: Polity Press.

Seo, W., \& Green, B. (2008). Development of the motivation scale for sport online consumption. Journal of Sport Management, 22, 82-109. doi:10.1123/jsm.22.1.82

Schivinski, B., Christodoulides, G., \& Dabrowski, D. (2016). Measuring consumers' engagement with brand-related social media content. Journal of Advertising Research, 56, 64-80. doi:10.2501/JAR2016-004

Schau, H., \& Gilly, M. (2003). We are what we post? Self-presentation in personal web space. Journal of Consumer Research, 30, 385-404. doi:10.1086/378616

Smock, A., Ellison, N., Lampe, C., \& Wohn, D. (2011). Facebook as a toolkit: A uses and gratification approach to unbundling feature use. Computers in Human Behaviour, 27, 2322-2329. doi:10.1016/ j.chb.2011.07.011

Smith, A., Fischer, E., \& Yongjian, C. (2012). How does brand-related user-generated content differ across YouTube, Facebook, and Twitter? Journal of Interactive Marketing, 26, 102-113. doi:10.1016/ j.intmar.2012.01.002

Statista. (2016). Number of monthly active Facebook users worldwide as of 3rd quarter 2016 (in millions). Author. Retrieved from https://www.statista.com/statistics/264810/number-of-monthly-activefacebook-users-worldwide/

Stavros, C., Meng, M., Westberg, K., \& Farrelly, F. (2014). Understanding fan motivation for interacting on social media. Sport Management Review, 17, 455-469. doi:10.1016/j.smr.2013.11.004

Sundar, S., \& Limperos, A. (2013). Uses and grats 2.0: New gratifications for new media. Journal of Broadcasting \& Electronic Media, 57, 504-525. doi:10.1080/08838151.2013.845827

Tsai, W., \& Men, L. (2013). Motivations and antecedents of consumer engagement with brand pages on social networking sites. Journal of Interactive Advertising, 13, 76-87. doi:10.1080/15252019.201 3.826549

Tsai, W., \& Men, L. (2017). Consumer engagement with brands on social network sites: A cross-cultural comparison of China and the USA. Journal of Marketing Communication, 23, 2-21. doi:10.1080/13 527266.2014.942678

vanDoorn, J., Lemon, K., Mittal, V., Nass, S., Pick, D., Pirner, P., \& Verhoef, P. (2010). Customer engagement behaviour:Theoretical foundations and research directions. Journal of Service Research, 13, 253-266. doi:10.1177/1094670510375599

Wakefield, K., \& Wann, D. (2006). An examination of dysfunctional sport fans: Method of classification and relationships with problem behaviors. Journal of Leisure Research, 38, 168-186.

Wallace, E., Buil, I., deChernatony, L., \& Hogan, M. (2014). Who "Likes" you ... and why? A typology of Facebook fans. Journal of Advertising Research, 54, 92-109. doi:10.2501/JAR-54-1-092-109 
Wallace, L., Wilson, J., \& Miloch, K. (2011). Sporting Facebook: A content analysis of NCAA organizational sport pages and Big 12 conference athletic department pages. International Journal of Sport Communication, 4, 422-444. doi:10.1123/ijsc.4.4.422

Whitemkaper, C., Lim, C., \& Waldburger, A. (2012). Social media and sports marketing: Examining the motivations and constraints of Twitter users. Sport Marketing Quarterly, 21, 170-183.

Williams, J., \& Chinn, S. (2010). Meeting relationship-marketing goals through social media: A conceptual model for sport marketers. International Journal of Sport Communications, 3, 422-437. doi:10.1123/ ijsc.3.4.422

Yoshida, M., Gordon, B., Nakazawa, M., \& Biscaia, R. (2014). Conceptualization and measurement of fan engagement: Empirical evidence from a professional sport context. Journal of Sport Management, 28, 399-417. doi:10.1123/jsm.2013-0199

Zaglia, M. (2013). Brand communities embedded in social networks. Journal of Business Research, 66, 216-223. doi:10.1016/j.jbusres.2012.07.015 


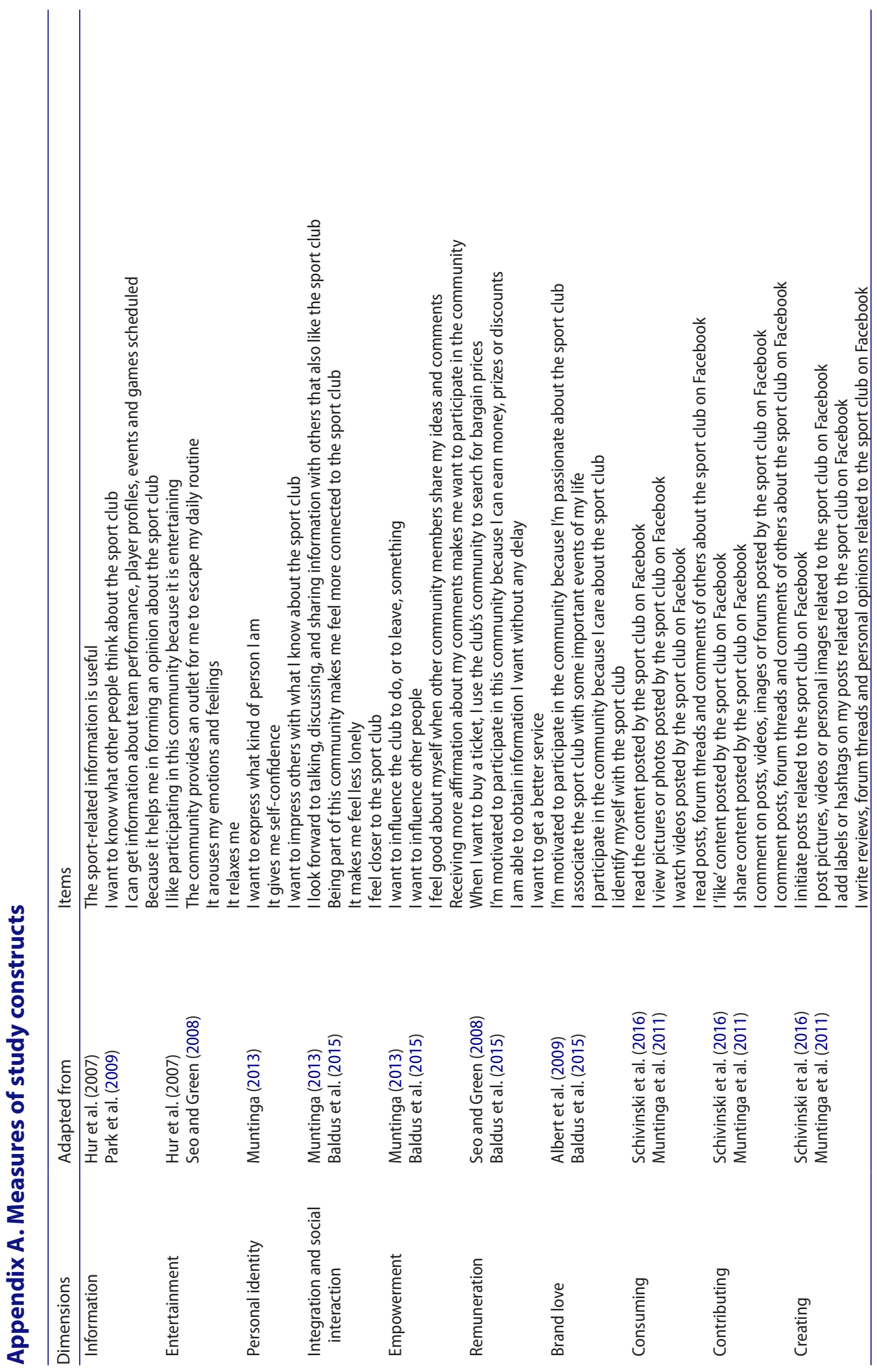

